\title{
Fit-for-Purpose Land Administration-Providing Secure Land Rights at Scale
}

\author{
Stig Enemark ${ }^{1, *}$, Robin McLaren ${ }^{2}$ and Christiaan Lemmen ${ }^{3,4}$ (D) \\ 1 Department of Planning, Aalborg University, 9000 Aalborg, Denmark \\ 2 Know Edge Ltd., Edinburgh EH14 1AY, UK; Robin.McLaren@KnowEdge.com \\ 3 School for Land Administration Studies, ITC Faculty, University of Twente, 7500 AE Enschede, \\ The Netherlands; chrit.lemmen@kadaster.nl \\ 4 Kadaster International, Cadastre, Land Registry and Mapping Agency, 7311 KZ Apeldoorn, The Netherlands \\ * Correspondence: enemark@plan.aau.dk
}

check for updates

Citation: Enemark, S.; McLaren, R.; Lemmen, C. Fit-for-Purpose Land Administration-Providing Secure Land Rights at Scale. Land 2021, 10, 972. https://doi.org/10.3390/ land10090972

Received: 6 September 2021 Accepted: 9 September 2021 Published: 15 September 2021

Publisher's Note: MDPI stays neutral with regard to jurisdictional claims in published maps and institutional affiliations.

Copyright: (C) 2021 by the authors. Licensee MDPI, Basel, Switzerland. This article is an open access article distributed under the terms and conditions of the Creative Commons Attribution (CC BY) license (https:// creativecommons.org/licenses/by/ $4.0 /)$.
This Special Issue provides an insight, collated from 26 articles, focusing on various aspects of the Fit-for-Purpose Land Administration (FFPLA) concept and its application. It presents some influential and innovative trends and recommendations for designing, implementing, maintaining and further developing FFP solutions for providing secure land rights at scale. The first group of 14 articles is published in Volume One and discusses various conceptual innovations related to spatial, legal and institutional aspects of FFPLA and its wider applications within land use management. The second group of 12 articles is published in Volume Two and focuses on case studies from various countries throughout the world, providing evidence and lessons learned from the FFPLA implementation process. However, in order to facilitate a more global understanding of the issues and their interrelationship, this editorial embraces both volumes. It should be noted, though, that the online version of this Special Issue presents the articles in a different order, namely in the chronology of their publication.

\section{Evolution of the FFPLA Approach}

The term "land administration" is rooted in cadastral and land registration systems originally developed for providing information about land value, land ownership and types of land use [1]. Historically, these systems were designed for slightly different purposes in various cultures, judicial systems and regions throughout the world. The key difference is whether the transaction alone is recorded (deeds systems) or the title itself is recorded and secured (title systems). The cultural and judicial aspects relate to whether a country is based on Roman law (deeds systems) or German or Anglo common law (title systems). This difference is also apparent in relation to the legacy of colonization.

A couple of decades ago, land administration emerged as a more generic term referred to as "the processes of determining, recording, and disseminating information about ownership, value, and use of land when implementing land management policies" [2,3]. This focus on information is still present, but, in recent years, the type and quality of information needed have changed and pushed the design of land administration systems (LASs) towards "an enabling infrastructure for implementing land policies and land management strategies in support of sustainable development" [4]. The operational components of this land governance infrastructure are the four functions of land tenure, land value, land use and land development. These four functions ensure the proper management of rights, restrictions, and responsibilities in relation to property, land use and natural resources, including the marine environment. However, the basis or the backbone of such solutions is the land tenure component related to the individual land parcel and establishing the relationship between people and land.

In most developed countries, security of tenure is taken for granted. Over centuries, these countries developed mature land institutions and laws that protect the people to 
land relationship and provide the services needed for supporting an efficient land market and effective land use management. However, an educated estimate indicates that for 70 percent of the world's population, this is not the case [5]. In most developing countries, people cannot register and safeguard their land rights, or it is too costly. The majority of these people are the poor and the most vulnerable in society. Therefore, over recent years, LASs have developed to also capture and include more informal and social types of tenure. This is encouraged and supported through the development of concepts such as the continuum of land rights [6], the social tenure domain model [7], and aspects of responsible governance of tenure $[8,9]$.

The key driver behind this evolution has been the overall global agenda focusing on poverty eradication, food security, gender equity, human rights, etc., as adopted by the Millennium Development Goals (MDGs) in 2000, and followed by the Sustainable Development Goals (SDGs) in 2015. This agenda has put a strong focus on security of land rights and provided targets and indicators for monitoring the progress of achieving the goals. Another key driver is technology development that has enabled easy access to new, innovative mapping and surveying techniques, such as satellite and drone imagery, mobile phones and handheld GPS, as well as techniques for the storage and management of huge datasets [10].

Over time, these evolutionary endeavors have been conceptualized in the FFPLA approach in 2014 designed to meet the challenges of providing secure land rights at scale [11, 12]. This FFP approach indicates that it is appropriate and of necessary standard for its main purpose ... namely providing secure land rights at scale within a given jurisdiction. The concept, as illustrated in Figure 1, includes three interrelated frameworks that work together to deliver the FFP approach: the spatial, legal and institutional frameworks.

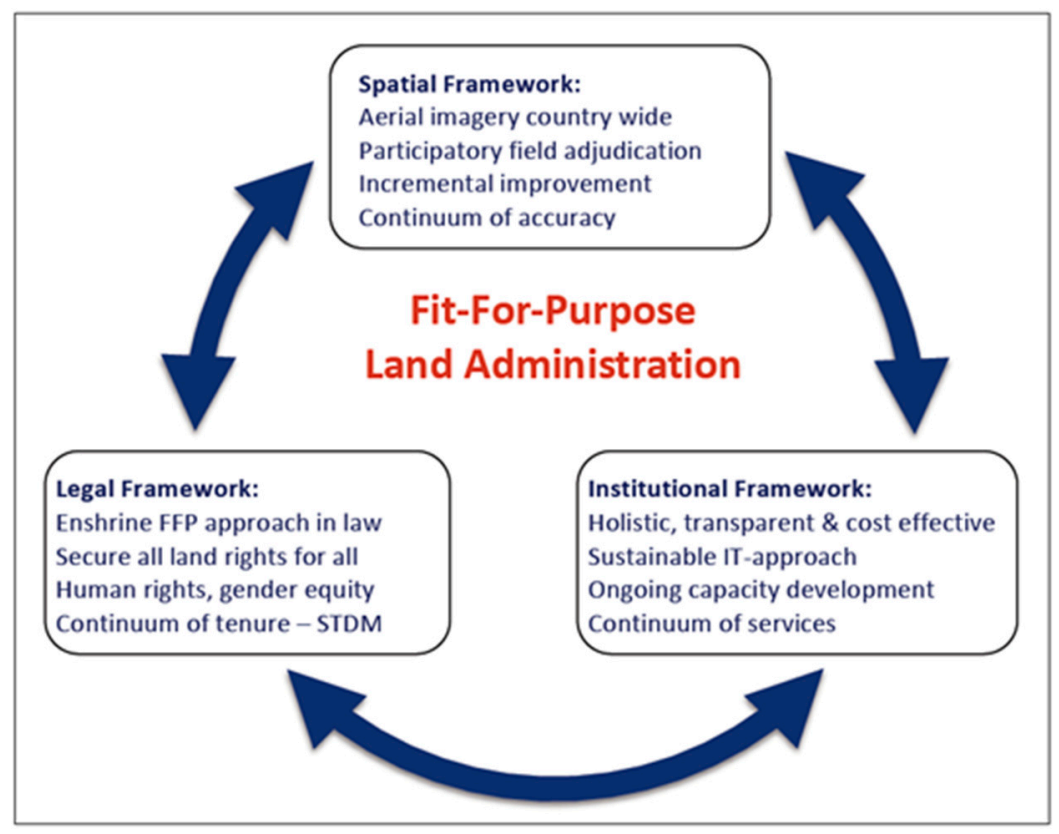

Figure 1. The FFPLA concept [12] (p. 17).

The spatial framework geospatially defines the way in which land is occupied and used. The scale and accuracy of this representation are not determined by rigid, high accuracy regulations, but instead by the users' requirements for effectively identifying the land parcels as a basis for securing the various kinds of legal and legitimate rights and tenure forms recognized through the legal framework. The institutional framework and partnerships are designed to manage these rights, the use of land and natural resources, and to deliver inclusive and accessible services. The approach is flexible, affordable, participatory, and the outcome is upgradeable over time [12]. 


\section{The FFPLA Special Issue}

In recent years, the FFPLA concept has been introduced in many countries throughout the world for providing secure land rights at scale, within a short timeframe and at affordable costs. Figure 2 shows the range of countries where FFPLA assessment and implementation are addressed in this Special Issue.

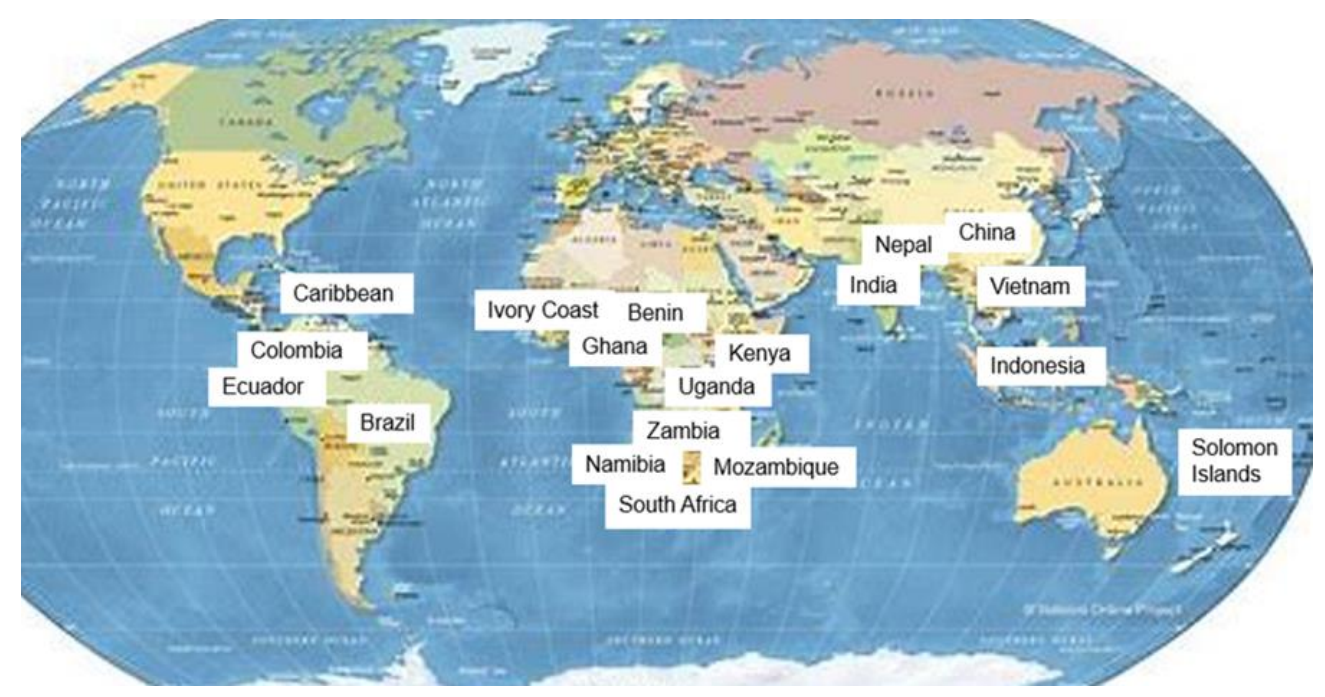

Figure 2. FFPLA Country assessments and implementations addressed in this Special Issue.

The first aim of this Special Issue is to present some recent innovations in the design and use of the FFPLA concept that are shaping new, more efficient approaches to FFPLA. This first group of 14 articles is published in Volume One. The second aim is to synthesize the experiences and lessons learned from country implementation in different cultures and jurisdictions throughout the world. This second group of 12 articles is published in Volume Two.

The conceptual innovations (Volume One) include issues such as:

(i) Assessing procedures of maintenance of conventional as well as unconventional systems;

(ii) Assessing adjudication and quality assurance for legal and geospatial data collected in the participatory processes of field work;

(iii) Applying innovative geospatial tools to FFPLA;

(iv) Using decentralization as a strategy for scaling FFPLA;

(v) Assessing the role of FFPLA for providing security of tenure in violent conflict settings;

(vi) Applying the FFP approach to wider land management functions and to urban resilience in times of climate change and the COVID-19 pandemic; and:

(vii) Exploring the role and opportunities of the private financial sector and public private partnerships within FFPLA.

These innovations are making the implementation of the FFPLA approach more efficient and widening the use in land management applications. Overall, these conceptual innovations are making the approach more attractive for countries to implement and allow the social and economic benefits to be realized more quickly for a sustainable future.

The experiences and lessons learned from country implementation (Volume Two) include cases such as:

(i) Assessing the development impacts of the processes used in China and Vietnam for providing secure land rights at scale;

(ii) Analyzing the strategy and implementation processes for applying an FFPLA approach in Indonesia, Nepal, Uganda and Mozambique;

(iii) Evaluating demonstrative cases of piloting a FFPLA approach and applying FFPLA tools for land recordation in Ghana, Kenya, Uganda, Zambia and Namibia;

(iv) Investigating the impact of applying the FFPLA approach to South Africa; 
(v) Using a FFP approach for upscaling of land administration in Benin;

(vi) Applying the FFPLA approach in response to post disasters in the Caribbean; and:

(vii) Assessing FFPLA applications in Colombia and Ecuador.

This wide range of country cases clearly demonstrates that the FFPLA approach is applicable within different contexts by reflecting the specific cultural, legal and institutional settings. The pilot cases validate that the FFPLA methodology for recording land rights in the field is flexible and is working effectively.

\section{Concluding Remarks}

The main motivation for this special edition was to share experiences and research into the FFPLA approach to help accelerate its implementation at scale and quickly resolve the global insecurity of tenure crisis. The articles indeed illustrate the significant progress that has been achieved over the past decade. They provide some very encouraging lessons learned, as well as exciting, innovative technologies to inspire land professionals to achieve the challenging objectives of the SDGs.

These new highlighted opportunities for going to scale include a clearer understanding of how to decentralize roles and responsibilities and manage organizational change. It also includes a better comprehension of how to obtain political support, gain consensus and formulate national FFPLA strategies, and new insights into implementing robust and the sustainable maintenance of land rights. The articles provide examples of obtaining alternative sources of financing for FFPLA through new types of PPPs, and a pioneering use of private social enterprises for embracing FFP land financing to support the regularization and upgrading of informal settlements. A range of technical innovations is presented, including greater efficiencies derived from the use of machine learning to extract information from drone imagery. Finally, and very importantly, the articles provide a rich set of experiences from FFPLA national scale implementations, as well as pilot projects from developing countries in three continents.

The articles also indicate that the impact of the FFP approach is unfolding beyond its initial focus on security of tenure. UN agencies are widely adopting FFPLA as a tool to mitigate underlying land issues in violent conflict settings, and it is being embraced in wider, urban land management functions to support housing resilience, property valuations, and mitigate the impact of climate change and pandemics. The articles confirm that the FFPLA approach is growing in acceptance across the land professional community, is gaining considerable momentum and is a game changer in achieving key elements of the global agenda, the SDGs, and the globally accepted policies and guidelines around responsible governance of tenure. The FFPLA is already triggering a change in society towards greater social equity, leaving no one behind.

\section{Overview of Contributions}

This Special Issue includes 26 articles divided into two groups: conceptual innovations (Volume One) and country implementations (Volume Two). The full list of articles is presented in Tables 1 and 2, each of which is followed by a short synthesis of the individual articles.

Bennett et al. [13] use an impressive range of contemporary sources to review FFPLA approaches from the perspective of system maintenance. The "fit-for-purpose" era is producing a wide range of new social and technological innovations; however, largescale and sustainable implementations still struggle with system maintenance. They present a consolidated model summarizing the story of the maintenance concept in land administration - in terms of key terminology, typologies, approaches, aspects and options. Then, they provide an overview of maintenance problems and related solutions. Finally, they identify that new solutions, as yet unpublished, and newly identified challenges, are emerging. 
Table 1. Conceptual Innovations.

\begin{tabular}{|c|c|c|c|}
\hline & Title & Country Focus & Application \\
\hline $\begin{array}{l}\text { Bennett } \\
\text { et al. }\end{array}$ & $\begin{array}{c}\text { Land Administration Maintenance: A review } \\
\text { of the Persistent Problem and Emerging } \\
\text { Fit-for-Purpose Solutions }\end{array}$ & Global & $\begin{array}{l}\text { Methodologies of } \\
\text { maintenance }\end{array}$ \\
\hline $\begin{array}{l}\text { Lengoiboni } \\
\text { et al. }\end{array}$ & $\begin{array}{l}\text { Initial Insights on Land Adjudication in a } \\
\text { Fit-for-Purpose Land Administration }\end{array}$ & Global & $\begin{array}{l}\text { Methodologies of } \\
\text { adjudication }\end{array}$ \\
\hline $\begin{array}{l}\text { Augustinus } \\
\text { and Tempra }\end{array}$ & $\begin{array}{l}\text { Fit-for-Purpose Land Administration in } \\
\text { Violent Conflict Settings }\end{array}$ & $\begin{array}{l}\text { Sudan, Iraq, } \\
\text { DRC, Honduras, } \\
\text { Peru, Somalia, }\end{array}$ & $\begin{array}{l}\text { Addressing land rights } \\
\text { in conflict settings }\end{array}$ \\
\hline Ho et al. & $\begin{array}{c}\text { Decentralization as a Strategy to Scale } \\
\text { Fit-for-Purpose Land Administration: An } \\
\text { Indian Perspective on Institutional } \\
\text { Challenges }\end{array}$ & India & $\begin{array}{l}\text { Decentralization as a } \\
\text { FFPLA tool }\end{array}$ \\
\hline $\begin{array}{l}\text { Mitchell } \\
\text { et al. }\end{array}$ & $\begin{array}{c}\text { The Benefits of Fit-for-Purpose Land } \\
\text { Administration for Urban Community } \\
\text { Resilience in a Time of Climate Change and } \\
\text { COVID-19 Pandemic }\end{array}$ & Solomon Islands & $\begin{array}{l}\text { FFPLA in support of } \\
\text { Improving urban } \\
\text { resilience }\end{array}$ \\
\hline Kelm et al. & $\begin{array}{l}\text { Applying the FFP Approach to Wider Land } \\
\text { Management Functions }\end{array}$ & Global & $\begin{array}{l}\text { The wider use of the } \\
\text { FFPLA approach }\end{array}$ \\
\hline $\begin{array}{l}\text { Childress } \\
\text { et al. }\end{array}$ & $\begin{array}{l}\text { Fit-for-Purpose, Private-Sector Led Land } \\
\text { Regularization and Financing of Informal } \\
\text { Settlements in Brazil }\end{array}$ & Brazil & $\begin{array}{l}\text { Applying a private } \\
\text { sector led approach }\end{array}$ \\
\hline Moran et al. & $\begin{array}{c}\text { Exploring PPPs in Support of Fit-for-Purpose } \\
\text { Land Administration: A Case Study from } \\
\text { Côte d'Ivoire }\end{array}$ & Ivory Coast & $\begin{array}{l}\text { Applying a PPP in } \\
\text { support of FFPLA }\end{array}$ \\
\hline $\begin{array}{l}\text { Reydon } \\
\text { et al. }\end{array}$ & $\begin{array}{c}\text { The Amazon Forest Preservation by } \\
\text { Clarifying Property Rights and Potential } \\
\text { Conflicts: How Experiments Using } \\
\text { Fit-for-Purpose Can Help }\end{array}$ & Brazil & $\begin{array}{l}\text { Applying a FFP } \\
\text { approach in support of } \\
\text { forest preservation }\end{array}$ \\
\hline Rocha et al. & $\begin{array}{l}\text { Quality Assurance for Spatial Data Collected } \\
\text { in Fit-for-Purpose Land Administration } \\
\text { Approaches in Colombia }\end{array}$ & Colombia & $\begin{array}{l}\text { Assessing the FFPLA } \\
\text { data quality }\end{array}$ \\
\hline $\begin{array}{l}\text { Hall and } \\
\text { Whittal }\end{array}$ & $\begin{array}{l}\text { Do Design Science Research and Design } \\
\text { Thinking Processes Improve the 'Fit' of the } \\
\text { Fit-for-Purpose Approach to Securing Land } \\
\text { Tenure for All in South Africa? }\end{array}$ & South Africa & $\begin{array}{l}\text { Exploring the use of } \\
\text { design science research } \\
\text { and design thinking } \\
\text { within FFPLA }\end{array}$ \\
\hline Koeva et al. & $\begin{array}{l}\text { Geospatial Tool and Geocloud Platform } \\
\text { Innovations: A Fit-for-Purpose Land } \\
\text { Administration Assessment }\end{array}$ & $\begin{array}{l}\text { Rwanda, Kenya, } \\
\text { Ethiopia, and } \\
\text { Zanzibar }\end{array}$ & $\begin{array}{l}\text { Assessing the use of } \\
\text { geospatial tools in Africa }\end{array}$ \\
\hline $\begin{array}{l}\text { Chipofya } \\
\text { et al. }\end{array}$ & $\begin{array}{l}\text { SmartSkeMa: Scalable Documentation for } \\
\text { Community and Customary Land Tenure }\end{array}$ & Global & $\begin{array}{l}\text { Spatial documentation } \\
\text { of community land } \\
\text { tenure }\end{array}$ \\
\hline Biraro et al. & $\begin{array}{c}\text { Good Practices in Updating Land } \\
\text { Information Systems that Used } \\
\text { Unconventional Approaches in Systematic } \\
\text { Land Registration }\end{array}$ & Global & $\begin{array}{l}\text { Updating practices in } \\
\text { unconventional land } \\
\text { registration }\end{array}$ \\
\hline
\end{tabular}

Lengoiboni et al. [14] explore how primary ('ownership') and secondary, overlapping ('non-ownership') interests in land are being adjudicated and recorded in a FFPLA context. They prepared questionnaires and developed criteria that organizations invited to answer the questionnaires must meet. They define the components of land adjudication. Then, the processes used by the organizations to achieve these components are described and insights are gained on how land tenure and land rights are framed and how this influences the outcomes of what is recorded. Results show that the legal perspective of land rights intersects with the perspective of communities regarding legitimate rights.

Augustinus and Tempra [15] tackle the challenging subject of UN peace keeping in violent conflict settings and examine how FFPLA interventions have become an integral part of the dispute and conflict resolution. They discuss seven cases across multiple countries and conflict sites where UN-Habitat either supported, or was directly involved in, UN peace keeping. They identify that land governance is of importance because of the way in which land-related power dynamics play out across the conflict cycle; the UN uses 
its power and capacity to strengthen land governance. They recommend that the FFPLA approaches provide practical options to support peace-building operations by the UN and other stakeholders.

Ho et al. [16] analyze the socio-political and institutional consequences of using decentralization as a scaling strategy for implementing FFPLA through three case studies in India. They review how decentralization is coordinated and governed across multiple levels. Their cases demonstrate a reduced role for the state, and a need for increased collaboration across a diverse set of stakeholders, including a greater number of nonstate actors at multiple levels. Although decentralization can work to effectively kickstart the implementation of FFPLA at scale, there is significant work required to ensure that implementation is "fit-for-people" to introduce a trustworthy system that redistributes power and distributes critical social justice.

Mitchell et al. [17] investigate the interlinkages between land tenure, climate vulnerability, and pandemics. Through research in Honiara, Solomon Islands, they consider how improving tenure security at scale through FFPLA can enhance climate resilience to mitigate vulnerability to both climate and pandemic impacts. They contend that this can be achieved at both the city and settlement levels by including tenure in vulnerability and risk assessments (VRA) and the development of resilience action plans. Their proposed FFPLA process, informed by participatory enumeration of the complexities of urban land tenure, can support scaling up efforts to improve tenure security, and deliver more effective and equitable climate resilience actions for vulnerable urban communities.

Kelm et al. [18] analyze how the FFP approach, which has predominantly been applied to the land tenure aspects, can be expanded into a wider set of land management functions. They test their hypothesis through three World Bank urban case studies focusing on land valuation, housing resilience and waste management. Machine learning techniques extract information from drone and street-level imagery to produce minimum viable product models. Their analysis has revealed that there is a common set of geospatial datasets that can be captured once and shared across many other land management functions in an urban environment. This will allow single land intervention projects to be holistically integrated into a wider program of land management functions.

Childress et al. [19] use the analysis of an innovative private social enterprise in Brazil, called Terra Nova, to demonstrate that the concept of FFP land regularization can be widened to include FFP land financing with relevance for wider efforts in informal settlement regularization and upgrading. Their analysis of parcel-level repayment and price data provides some evidence of the sustainability of the business model and the increase of property values of the regularized parcels (pre-COVID-19). Since 2001, Terra Nova has regularized over 20,000 parcels, primarily in São Paolo and Curitiba. They contend that the approach is widely replicable.

Morán et al. [20] introduce a new, innovative form of public private partnership (PPP) being piloted in the coffee growing areas of Côte d'Ivoire, that includes a partnership between the Government and a consortium of cocoa industry leaders and Meridia, the Dutch private land documentation firm. The private sector companies provide funding and service delivery, while the Government enables a political environment for interventions, provides in-kind contributions, collaborates in the execution of projects, and operates the land information system/registry to which the consortium's service connects. This PPP approach could potentially provide countries with alternatives to donor funding/loans.

Reydon et al. [21] blame deforestation in Brazil on the absence of cadastral mapping, land registration, and an effective regulation of property rights. This already involves some 200 million hectares, mostly on public land or undesignated land. This land is easy to grab, deforest and to be used for speculative purposes. The availability of well-defined land rights can reduce the process of deforestation. Participatory determination of land rights based on FFPLA methodologies promotes forest preservation. They hope that their methodology for determining the land rights of small landholders and of traditional popu- 
lation landholders will become mainstream. This will require some legal and institutional adjustments in order to improve the sustainability of the Amazon rainforest.

Rocha et al. [22] present a FFPLA quality assurance model for the evaluation of the quality of the geospatial data collected in the Municipality of Apartadó in Colombia. The FFPLA approach allowed the right holders to walk their parcel boundaries using a smartphone application connected to a GPS receiver to collect their boundary data points. The project evaluated how well the FFPLA dataset conformed to its product specification and was able to determine whether FFPLA data were of sufficient quality, specifically in the case of positional accuracy and logical consistency. The model supported the creation of a product quality life cycle and a quality model in the Colombian context.

Hull and Whittal [23] conduct a reflective retrospective of the processes of land administrative reform in South Africa to determine how land administration systems should be reshaped and new land tenure reforms to be developed. They adopt a thematic framework that innovatively combines FFPLA, design science research, and design thinking processes to help to unlock sensitive and empathetic innovations in land administration systems reform initiatives that will deliver restorative justice. These approaches should be embedded into FFPLA at the start. They admit that this is new and untested and they encourage case studies explicitly implementing these additional approaches in land administration reform.

Koeva et al. [24] assess a series of innovative tools recently developed within the framework of a European Commission Horizon 2020 project. The tools they review are designed to effectively apply FFPLA approaches and are based on requirements from FFPLA projects in Rwanda, Kenya, Ethiopia and Zanzibar. The study was conducted under the appealing title "its4land". The tools include software that implements the smart sketch mapping concept, a workflow for data acquisition based on unmanned aerial vehicles, and a boundary delineator tool based on semi-automatic feature extraction from UAV images. The 'Publish and Share' platform enables the integration of all the outputs of tool sharing and publishing of land information through geocloud web services.

Chipofya et al. [25], with a reference to the 'landmarkmap database', point out that fifty percent of habitable land on this planet is held by indigenous communities. There are no proper tools to document these rights quickly and effectively. Existing software and facilities for documentation of these rights still assume parcel-oriented thinking with statutory rights. The Smart Sketch Map (SmartSkeMa) allows people to document their land rights using concepts from their everyday experiences. SmartSkeMa supports both the legibility of customary land tenure to government authorities and the preservation of the customs within which the tenure relations operate.

Biraro et al. [26] study the maintenance of data in land information systems for which the data were obtained using unconventional approaches. The paper proves that there are good, recommendable practices in the selected countries, including infrastructure for updating; simplified systems; reasonable registration fees; decentralized services; accessible and secured digital databases; awareness raising about registration; availability of a legal framework; incentives to motivate people to report transactions on time; and trained staff and political support. The authors conclude that efforts are still needed to shorten updating procedures, introduce data-sharing platforms, ensure financial and technical sustainability, and reduce the number of involved institutions. 
Table 2. Country Implementations.

\begin{tabular}{|c|c|c|c|}
\hline & Title & $\begin{array}{l}\text { Country } \\
\text { Focus }\end{array}$ & Application \\
\hline Byamugisha & $\begin{array}{c}\text { Experiences and Development Impacts of } \\
\text { Securing Land Rights at Scale in } \\
\text { Developing Countries: Case Studies of } \\
\text { China and Vietnam }\end{array}$ & $\begin{array}{l}\text { China, } \\
\text { Vietnam }\end{array}$ & $\begin{array}{l}\text { Securing land rights at } \\
\text { scale in China and } \\
\text { Vietnam }\end{array}$ \\
\hline Martono et al. & $\begin{array}{l}\text { The Legal Element of Fixing the Boundary } \\
\text { for Indonesian Complete Cadastre }\end{array}$ & Indonesia & $\begin{array}{l}\text { Applying FFPLA in } \\
\text { Indonesia }\end{array}$ \\
\hline Panday et al. & $\begin{array}{l}\text { Securing Land Rights for All through } \\
\text { Fit-for-Purpose Land Administration } \\
\text { Approach: The Case of Nepal }\end{array}$ & Nepal & $\begin{array}{l}\text { Applying FFPLA in } \\
\text { Nepal }\end{array}$ \\
\hline Musinguzi et al. & $\begin{array}{l}\text { Fit for Purpose Land Administration: } \\
\text { Country Implementation Strategy for } \\
\text { Addressing Uganda's Land Tenure } \\
\text { Security Problems }\end{array}$ & Uganda & $\begin{array}{l}\text { Applying FFPLA in } \\
\text { Uganda }\end{array}$ \\
\hline Chigbu et al. & $\begin{array}{l}\text { Fit-for-Purpose Land Administration from } \\
\text { Theory to Practice: Three Demonstrative } \\
\text { Case Studies of Local Land Administration } \\
\text { Initiatives in Africa }\end{array}$ & $\begin{array}{l}\text { Ghana, Kenya, } \\
\text { Namibia }\end{array}$ & $\begin{array}{l}\text { Applying FFPLA } \\
\text { approaches in Africa }\end{array}$ \\
\hline Antonio et al. & $\begin{array}{l}\text { Transforming Land Administration } \\
\text { Practices through the Application of } \\
\text { Fit-for-Purpose Technologies: Country } \\
\text { Case Studies in Africa }\end{array}$ & $\begin{array}{l}\text { Uganda, } \\
\text { Kenya, } \\
\text { Zambia }\end{array}$ & $\begin{array}{l}\text { Applying the STDM in } \\
\text { Africa }\end{array}$ \\
\hline Mekking et al. & $\begin{array}{l}\text { Fit-for-Purpose Upscaling Land } \\
\text { Administration-A Case Study from Benin }\end{array}$ & Benin & $\begin{array}{l}\text { Applying FFPLA in } \\
\text { Benin }\end{array}$ \\
\hline Balas et al. & $\begin{array}{l}\text { The Fit for Purpose Land Administration } \\
\text { Approach-Connecting People, Processes } \\
\text { and Technology in Mozambique }\end{array}$ & Mozambique & $\begin{array}{l}\text { Applying FFPLA in } \\
\text { Mozambique }\end{array}$ \\
\hline Williams-Wynn & $\begin{array}{l}\text { Applying the Fit-for-Purpose Land } \\
\text { Administration Concept to South Africa }\end{array}$ & South Africa & $\begin{array}{l}\text { Assessment of applying } \\
\text { FFPLA in South Africa }\end{array}$ \\
\hline Griffith-Charles & $\begin{array}{c}\text { Application of FFPLA to Achieve } \\
\text { Economically Beneficial Outcomes Post } \\
\text { Disaster in the Caribbean }\end{array}$ & $\begin{array}{l}\text { Caribbean } \\
\text { Islands }\end{array}$ & $\begin{array}{l}\text { Applying FFPLA in the } \\
\text { Caribbean }\end{array}$ \\
\hline Becerra et al. & $\begin{array}{c}\text { Fit-for-Purpose Applications in Colombia: } \\
\text { Defining Land Boundary Conflicts between } \\
\text { Indigenous Sikuani and Neighbouring } \\
\text { Settler Farmers }\end{array}$ & Colombia & $\begin{array}{l}\text { Applying FFPLA in } \\
\text { Colombia }\end{array}$ \\
\hline Todorovski et al. & $\begin{array}{c}\text { Assessment of Land Administration in } \\
\text { Ecuador Based on the Fit-for-Purpose } \\
\text { approach }\end{array}$ & Ecuador & $\begin{array}{l}\text { Assessment of applying } \\
\text { FFPLA in Ecuador }\end{array}$ \\
\hline
\end{tabular}

Byamugisha [27] details, for the first time, the journeys that China and Vietnam embraced to register all land rights within their countries. This formidable task was triggered when the countries decollectivized agricultural production and allocated rural land to farming households in the 1980s and 1990s; about 1.5 billion rural arable land parcels in China and about 70 million in Vietnam. This was in addition to registering the urban land rights. In both countries, the registration of rural land was done in two rounds and the FFPLA approach was adopted. He distills an excellent set of lessons learned and challenges, and these should inform other countries embarking on similar security of tenure journeys to eradicate extreme poverty.

Martono et al. [28] aim to establish the distinction between physical and legal elements in determining cadastral boundaries in Indonesia. Interviews were conducted for this purpose, and six "cadastral elements" have been investigated and assessed: the parties that locate the boundary, the agreement between the adjoining landowners, the use of boundary markers, the role of the determination officer, the survey method, and the accuracy of the base map. Agreements could be obtained using aerial imagery instead of a field survey. Fixed boundary with exact coordinates based on prescribed survey methods, and with the accuracy of base map, as required by regulations, is not important to people in rural areas.

Panday et al. [29] analyze two pilot studies designed for testing the implementation of a FFPLA National Strategy in Nepal for providing security of tenure for 10 million 
land parcels currently outside the formal land registration system. They present the methodological workflow of this action-oriented research using one pilot study in an urban setting, including about 1500 spatial units of informal settlements, while the other is rural with 3400 arable land parcels. They explain how the results validate the FFPLA national implementation strategy approach designed for the specific and complex Nepal country context, and they argue that this methodology may be applicable for other low-income countries, where a large amount of the land is informally occupied.

Musinguzi et al. [30] explore, in great depth, the process of developing a national strategy for providing secure land rights at scale in Uganda, covering 23 million land parcels. They describe the current tenure types in Uganda and examine three representative pilot projects, in order to identify how lessons learned from these case studies informed a FFPLA implementation strategy in terms of building the spatial, legal and institutional frameworks. They highlight how pilot projects can provide opportunities for explaining benefits to obtain the necessary political, community and stakeholder support. In conclusion, they argue that a country implementation strategy, if developed as a result of a national dialogue and consensus among all stakeholders, is a promising way of advancing the FFPLA concept.

Chigbu et al. [31] provide evidence that the FFPLA approach represents an unprecedented opportunity to provide tenure security in Africa. They use three country case studies based on hands-on, local land administration projects to demonstrate how the features of the FFPLA guidelines were adopted. Support is provided for the understanding that high-precision measurements are not necessary for legal certainty. They conclude that local people, including youth and women, can be used for data collection and cadastral mapping purposes that are both inexpensive and can be used as necessary documentation for the promotion of tenure security.

Antonio et al. [32] investigate whether the STDM (social tenure domain model) tool facilitates the improvement of land tenure security. The STDM provides a flexible way to meet local needs in capturing human-country relationships. The tool is internationally recognized as practical, fast, and affordable. Their study shows that the STDM can be effectively applied to establish the spatial framework for land administration and to facilitate the implementation of land tenure security of poor communities. Focusing on one pillar of FFPLA can influence positive changes in other frameworks of the FFPLA concept through the use and application of technology, such as the STDM tool.

Mekking et al. [33] present a case study from Benin, with a focus on upscaling the FFPLA approach. At present, only 60,000 of the estimated 5 million plots are registered. For a parcel of $500 \mathrm{~m}^{2}$, the cost of a title amounts to 540 USD, which is unaffordable for the vast majority of the population. The Benin Government wants legal security for all, and the FFPLA approach offers the opportunity to achieve this. The core of their approach is the introduction of a tenure system based on presumed ownership in parallel to the existing title system. Right holders then have the option to move from "presumed" ownership to state-guaranteed ownership.

Balas et al. [34] provide evidence from Mozambique that the FFPLA approach works. The former "Terra Segura" programme lasted four years and provided only 220,000 parcels and boundaries of 400 communities out of a set target of 5 million plots. The average costs were 50 USD per parcel and 10,000 USD per community. This is too expensive. A fundamentally different FFPLA approach was needed. The FFPLA-MOZ approach was developed and resulted in a better performance and a cost per parcel of 15 USD and 2000 USD for a community boundary definition. From the end of 2017 to March 2020, almost 1.4 million parcels and 826 community delimitations have been processed.

Williams-Wynn [35], the Surveyor General, investigates whether South Africa can adopt FFPLA to provide security of tenure for the five million land occupants that exist outside the formal land tenure system. As Surveyor General, he uses South Africa as a case study to demonstrate how adjustments to institutional, legal and spatial frameworks will develop a fully inclusive, sufficiently accurate land administration system that fits the pur- 
pose for which it is envisioned. He is optimistic that the adoption of the FFPLA approach with political support, trust built through community participation, and endorsement of the approach by land professionals will provide security of tenure that is beneficial to all.

Griffith-Charles [36] reviews the experiences with adjudication and titling being undertaken by countries of the Caribbean, with specific examples from Trinidad and Tobago, Barbados, and Jamaica, and others. Her assessment identifies that many countries had spent a lot of time, money, and effort, but were still without a predicted time of completion. The unhurried progress in some countries can be accelerated through the adoption of the FFPLA principles. She reasons that an essential aspect of achieving economically beneficial results is for a country to first identify and publicize a clear vision and objective of what is to be achieved, which requires land-related solutions to be efficient and inclusive.

Becerra et al. [37] introduce a FFPLA approach to support conflict resolution related to overlapping land claims. Indigenous people in Coumaribo, Colombia encounter landrelated conflicts with newly arrived and established farmers. The methodology involves both parties independently surveying their land claims. This results in representations of the claims in georeferenced polygons, making any overlaps visible. In a public inspection, the results of the field measurements are displayed, with the presence of the cadastral authority. Discussing the results with all stakeholders helps to clarify the conflicts, to reduce the conflict to specific, relatively small, geographical areas, and to define concrete steps towards solutions.

Todorovski et al. [38] present an assessment of the existing land administration in Ecuador based on the spatial, legal and institutional frameworks - and related principlesof the FFPLA approach. This assessment is used to make recommendations for the improvement of the existing land administration to make the Government's plans for the implementation of a country-wide land administration system more feasible. They identify principles in a developed score table with a low and medium alignment that need to be addressed and adapted to a FFPLA approach; specifically with interventions in the current requirements for the precise measurement of fixed boundaries and a large number of text attributes collected in rural areas.

Author Contributions: S.E.: visualization, conceptualization and writing—original draft preparation. R.M.: conceptualization, writing-review and editing. C.L.: conceptualization, writing-review and editing. All authors have read and agreed to the published version of the manuscript.

Funding: The funding of the publication costs for this editorial, as well as the 26 articles included in this Special Issue, has kindly been provided by the School of Land Administration Studies, Faculty of ITC from the University of Twente, in combination with Kadaster International, The Netherlands.

Institutional Review Board Statement: Not applicable.

Informed Consent Statement: Not applicable.

Data Availability Statement: Not applicable.

Acknowledgments: The authors, as guest editors, would like to acknowledge the contributions of the authors of the individual articles included in this Special Issue, as well as all the external reviewers involved in assessing the scientific level of the manuscripts. We would also like to acknowledge the support of colleagues of academic and government originations that supported this work, in particular the School of Land Administration, Faculty of ITC from the University of Twente, in combination with Kadaster International, The Netherlands.

Conflicts of Interest: The authors declare no conflict of interest.

\section{References}

1. International Federation of Surveyors (FIG). The FIG Statement on the Cadastre; FIG Publication No. 11; FIG: Copenhagen, Denmark, 1995.

2. United Nations Economic Commission for Europe (UNECE). Land Administration Guidelines: With Special Reference to Countries in Transition; UNECE: Geneva, Switzerland; New York, NY, USA, 1996.

3. Dale, P.; McLaughlin, J. Land Administration; Oxford University Press: Oxford, UK, 1999. 
4. Williamson, I.; Enemark, S.; Wallace, J.; Rajabifard, A. Land Administration for Sustainable Development; ESRI Academic Press: Redlands, CA, USA, 2010.

5. McLaren, R. How Big Is Global Insecurity of Tenure? Geomares Publishing: Lemmer, The Netherlands, 2015.

6. Global Land Tool Network (GLTN). Secure Land Rights for All; UN-Habitat: Nairobi, Kenya, 2008.

7. FIG/GLTN. The Social Tenure Domain Model; FIG Publication No. 52; FIG: Copenhagen, Denmark, 2010.

8. Food and Agriculture Organization of the United Nations (FAO). Voluntary Guidelines on the Responsible Governance of Tenure of Land, Fisheries and Forests in the Context of Food Security; FAO: Rome, Italy, 2012.

9. Zevenbergen, J.; De Vries, W.; Bennett, R. (Eds.) Advances in Responsible Land Administration; CRC Press: Boca Raton, FL, USA, 2016.

10. World Bank. New Technology and Emerging Trends: The State of Play for Land Administration; World Bank: Washington, DC, USA, 2017

11. Enemark, S.; Bell, K.C.; Lemmen, C.; McLaren, R. Fit-for-Purpose Land Administration; FIG Publication No 60. Joint Publication; International Federation of Surveyors (FIG), World Bank: Copenhagen, Denmark, 2014.

12. Enemark, S.; McLaren, R.; Lemmen, C. Fit-for-Purpose Land Administration-Guiding Principles for Country Implementation; GLTN; UN-Habitat: Nairobi, Kenya, 2016.

13. Bennett, R.M.; Unger, E.-M.; Lemmen, C.; Dijkstra, P. Land Administration Maintenance: A Review of the Persistent Problem and Emerging Fit-for-Purpose Solutions. Land 2021, 10, 509. [CrossRef]

14. Lengoiboni, M.; Richter, C.; Aspersen, P.; Zevenbergen, J. Initial Insights on Land Adjudication in a Fit-for-Purpose Land Administration. Land 2021, 10, 414. [CrossRef]

15. Augustinus, C.; Tempra, O. Fit-for-Purpose Land Administration in Violent Conflict Settings. Land 2021, 10, 139. [CrossRef]

16. Ho, S.; Choudhury, P.R.; Haran, N.; Leshinsky, R. Decentralization as a Strategy to Scale Fit-for-Purpose Land Administration: An Indian Perspective on Institutional Challenges. Land 2021, 10, 199. [CrossRef]

17. Mitchell, D.; Barth, B.; Ho, S.; Sait, M.S.; McEvoy, D. The Benefits of Fit-for-Purpose Land Administration for Urban Community Resilience in a Time of Climate Change and COVID-19 Pandemic. Land 2021, 10, 563. [CrossRef]

18. Kelm, K.; Antos, S.; McLaren, R. Applying the FFP Approach to Wider Land Management Functions. Land 2021, $10,723$. [CrossRef]

19. Childress, M.; Carter, S.; Barki, E. Fit-for-Purpose, Private-Sector Led Land Regularization and Financing of Informal Settlements in Brazil. Land 2021, 10, 797. [CrossRef]

20. Morán, A.G.; Ulvund, S.; Unger, E.-M.; Bennett, R.M. Exploring PPPs in Support of Fit-for-Purpose Land Administration: A Case Study from Côte d'Ivoire. Land 2021, 10, 892. [CrossRef]

21. Reydon, B.; Molendijk, M.; Porras, N.; Siqueira, G. The Amazon Forest Preservation by Clarifying Property Rights and Potential Conflicts: How Experiments Using Fit-for-Purpose Can Help. Land 2021, 10, 225. [CrossRef]

22. Rocha, L.A.; Montoya, J.; Ortiz, A. Quality Assurance for Spatial Data Collected in Fit-for-Purpose Land Administration Approaches in Colombia. Land 2021, 10, 496. [CrossRef]

23. Hull, S.; Whittal, J. Do Design Science Research and Design Thinking Processes Improve the 'Fit' of the Fit-for-Purpose Approach to Securing Land Tenure for All in South Africa? Land 2021, 10, 484. [CrossRef]

24. Koeva, M.; Humayun, M.I.; Timm, C.; Stöcker, C.; Crommelinck, S.; Chipofya, M.; Bennett, R.; Zevenbergen, J. Geospatial Tool and Geocloud Platform Innovations: A Fit-for-Purpose Land Administration Assessment. Land 2021, 10, 557. [CrossRef]

25. Chipofya, M.; Jan, S.; Schwering, A. SmartSkeMa: Scalable Documentation for Community and Customary Land Tenure. Land 2021, 10, 662. [CrossRef]

26. Biraro, M.; Zevenbergen, J.; Alemie, B.K. Good Practices in Updating Land Information Systems that Used Unconventional Approaches in Systematic Land Registration. Land 2021, 10, 437. [CrossRef]

27. Byamugisha, F.F.K. Experiences and Development Impacts of Securing Land Rights at Scale in Developing Countries: Case Studies of China and Vietnam. Land 2021, 10, 176. [CrossRef]

28. Martono, B.; Aditya, T.; Subaryono and, S.; Nugroho, P. The Legal Element of Fixing the Boundary for Indonesian Complete Cadastre. Land 2021, 10, 49. [CrossRef]

29. Panday, U.S.; Chhatkuli, R.R.; Joshi, J.R.; Deuja, J.; Antonio, D.; Enemark, S. Securing Land Rights for All through Fit-for-Purpose Land Administration Approach: The Case of Nepal. Land 2021, 10, 744. [CrossRef]

30. Musinguzi, M.; Enemark, S.; Mwesigye, S.P. Fit for Purpose Land Administration: Country Implementation Strategy for Addressing Uganda's Land Tenure Security Problems. Land 2021, 10, 629. [CrossRef]

31. Chigbu, U.E.; Bendzko, T.; Mabakeng, M.R.; Kuusaana, E.D.; Tutu, D.O. Fit-for-Purpose Land Administration from Theory to Practice: Three Demonstrative Case Studies of Local Land Administration Initiatives in Africa. Land 2021, 10, 476. [CrossRef]

32. Antonio, D.; Njogu, S.; Nyamweru, H.; Gitau, J. Transforming Land Administration Practices through the Application of Fit-for-Purpose Technologies: Country Case Studies in Africa. Land 2021, 10, 538. [CrossRef]

33. Mekking, S.; Kougblenou, D.V.; Kossou, F.G. Fit-for-Purpose Upscaling Land Administration-A Case Study from Benin. Land 2021, 10, 440. [CrossRef]

34. Balas, M.; Carrilho, J.; Lemmen, C. The Fit for Purpose Land Administration Approach-Connecting People, Processes and Technology in Mozambique. Land 2021, 10, 818. [CrossRef]

35. Williams-Wynn, C. Applying the Fit-for-Purpose Land Administration Concept to South Africa. Land 2021, 10, 602. [CrossRef] 
36. Griffith-Charles, C. Application of FFPLA to Achieve Economically Beneficial Outcomes Post Disaster in the Caribbean. Land 2021, 10, 475. [CrossRef]

37. Becerra, L.; Molendijk, M.; Porras, N.; Spijkers, P.; Reydon, B.; Morales, J. Fit-for-Purpose Applications in Colombia: Defining Land Boundary Conflicts between Indigenous Sikuani and Neighbouring Settler Farmers. Land 2021, 10, 382. [CrossRef]

38. Todorovski, D.; Salazar, R.; Jacome, G. Assessment of Land Administration in Ecuador Based on the Fit-for-Purpose Approach. Land 2021, 10, 862. [CrossRef] 